\title{
MAKNA PERIBAHASA MADURA DAN STEREOTIP KEKERASAN PADA ETNIS MADURA (TINJAUAN STILISTIKA)
}

\author{
Anandika Panca Nugraha
}

anand.nugraha@gmail.com

Universitas Airlangga

Surabaya, Jawa Timur, Indonesia

\begin{abstract}
This article studies the meaning of Madurese proverbs commonly associated with violence stereotype of the Madurese. The analysis is conducted by using stylistic approach while the data are collected by means of documentary method. The findings show that Madurese proverbs represent a number of meanings related to violence, that is, physical violence, robust conviction and advice on violence. Those meanings do not necessarily justify the violent nature of the Madurese. Rather, they much imply the principles of Madurese people to strongly uphold self dignity, courage and righteousness. Further research using larger data of Madurese proverbs and other types of Madurese proverbs is suggested in order to obtain comprehensive depiction about Madurese values.
\end{abstract}

Keywords: proverb, stylistics, foregrounding, violence stereotype, ethnic Madurese

\section{PENDAHULUAN}

Peribahasa merupakan ungkapan singkat berisi nasihat atau sesuatu yang secara akal sehat dinilai benar atau bijak. Ia muncul sebagai produk pengalaman praktis dari hubungan kemanusiaan (Efawati, 2013, h. 13). Secara spesifik, Mieder (2004, h. 3) mendefinisikan peribahasa sebagai kalimat pendek yang dikenal masyarakat berisi nilainilai kebijaksanaan, kebenaran, moral dan pandangan tradisional dalam bentuk metaforis, baku, mudah diingat serta diwariskan dari generasi ke generasi. Maka, dapat dikatakan bahwa peribahasa merupakan salah satu bentuk tradisi (folklor) lisan yang dapat merepresentasikan kearifan lokal sebuah kelompok masyarakat/etnis.

Unsur utama peribahasa adalah bahasa figuratif. Dengan bahasa figuratif, peribahasa akan lebih mampu memberikan efek estetis maupun emotif kepada pendengarnya. Unsur figuratif dalam peribahasa mencakup sarana puitis yang menyiasati struktur lahir, seperti aliterasi dan paralelisme serta sarana yang meningkatkan efek retoris, misalnya metafora, hiperbola, sinekdoki dan metonimi. Di antara unsur-unsur tersebut, metafora merupakan elemen paling signifikan karena sifatnya yang menyampaikan makna secara tidak langsung sehingga sesuai dengan karakteristik peribahasa sebagai folklor lisan yang fitur utamanya adalah ketidaklangsungan atau indirectness dan non-literalness (Grzybek, 2014, h. 78). Dengan demikian, terdapat efek penonjolan (foregrounding) semantis yang membuat peribahasa mudah diingat.

Indonesia sebagai negara multi etnis kaya dengan peribahasa lokal. Setiap suku pasti memiliki bentuk-bentuk peribahasa khas yang khas. Dalam masyarakat Jawa, misalnya, terdapat paribasan Jawa, dalam masyarakat etnis melayu terdapat pepatah Melayu, dalam masyarakat Sunda terdapat peribahasa Sunda, dalam masyarakat Madura terdapat $c a^{\prime}-o c a^{\prime} a n$ Madura, dan lain-lain. Artikel ini secara spesifik hanya akan mengkaji peribahasa dalam masyarakat etnis Madura. Kemudian, peribahasa yang dimaksud hanya difokuskan pada peribahasa yang memiliki relasi dengan stereotip kekerasan. Sementara, perspektif yang digunakan adalah perspektif stilistika karena diharapkan dengan pendekatan 
tersebut peran bahasa figuratif sebagai elemen sentral peribahasa dalam mengekspresikan makna secara estetis/puitis dapat dipahami.

Peribahasa dan stereotip kekerasan dalam masyarakat Madura ini menarik dikaji karena dalam praktiknya peribahasa yang sebenarnya memiliki pesan moral tentang keberanian, pembelaan terhadap martabat dan kebenaran justru disalahgunakan oleh sebagian orang Madura sendiri untuk membenarkan tindakan kekerasan atau sering dikenal dengan istilah carok yang mereka lakukan untuk menyelesaikan persoalan.

Dalam masyarakat Madura istilah peribahasa ini dikenal dengan istilah $c a^{\prime}$ oca'an yang secara literal berarti "ucapanucapan". Ca'-oca'an juga kental dengan penggunaan gaya bahasa figuratif, baik yang bermain dengan struktur lahir maupun deviasi makna. Misalnya, paralelisme ta' atane ta' atana' (tidak bertani, tidak menanak nasi), simile akanta bulan kaseyangan (seperti bulan kesiangan), dan lain-lain. Sebagai produk tradisi lisan, $c a^{\prime}$-oca'an juga merefleksikan kultur etnis pencipta dan penggunanya. $\mathrm{Ca}^{\prime}$ oca'an mencerminkan sejumlah hal, antara lain nilai, pembawaan, sifat, perilaku, penampilan, hakikat karya dan etos kerja, interaksi antar sesama, lingkungan fisik dan lingkungan sosialnya serta pandangan dunia dan perjuangan hidup suku Madura (Rifai, 2007, h. 198).

Sampai sejauh ini terdapat sejumlah kajian tentang peribahasa Madura dari berbagai perspektif. Di antaranya adalah kajian yang dilakukan oleh Rifai (2007), Efawati (2013), dan Misnadin (2012). Akan tetapi, kajian tersebut tidak secara khusus berfokus mengkaji peribahasa Madura yang dikaitkan dengan stereotip kekerasan. Rifai (2007) menggunakan perspektif sosiologis antropologis dalam mendeskripsikan pembawaan, perilaku, etos kerja, penampilan, dan pandangan hidup orang Madura seperti dicitrakan dalam peribahasanya. Efawati (2013) lebih menekankan pada kajian semantik sementara Misnadin (2012) berusaha memahami dan menafsirkan kembali pepatah-pepatah Madura dengan tema beragam guna merevitalisasi nilai nilai yang terkandung di dalamnya. Padahal, kajian mengenai hubungan peribahasa dengan kekerasan sangat penting dilakukan untuk memahami dan merespons fenomena kekerasan yang dilakukan etnis Madura secara proporsional. Sehingga, stereotip yang telanjur terbentuk tentang orang Madura yang keras dapat dievaluasi.

\section{Stilistika}

Telah dijelaskan bahwa peribahasa dalam artikel ini dikaji dari perspektif stilistika yang merupakan ilmu tentang gaya bahasa (style). Disiplin ini merupakan usaha linguistik untuk menganalisis teks sastra secara objektif melalui perspektifdan unsurunsur linguistik dari teks sastra tersebut. Dalam perkembangannya, stilistika juga diaplikasikan untuk menganalisis teks nonsastra, baik lisan maupun tulis (Wales, 2011, h. 401).

Tujuan utama kajian stilistika adalah untuk menunjukkan bagaimana sebuah teks menyampaikan makna yang dikandungnya dengan mendeskripsikan unsur-unsur formalnya, seperti diksi, struktur kalimat, dan lain-lain serta menjelaskan dampak fungsional setiap unsur itu terhadap proses interpretasi makna teks tersebut (Wales, 2011, h. 400).Unsur formal tersebut secara kolektif membentuk karakteristik style sebuah teks. Semakin khas dan efektif pemilihan unsurnya, maka teks tersebut semakin efektif menyampaikan maknanya sekaligus menciptakan efek estetis bagi audiens. Karena itu, sastrawan Jonathan Swift menyebut style sebagai proper words in proper places (Crystal, 1987, h. 66).

Salah satu cara menciptakan style yang menarik adalah dengan memanfaatkan bahasa figuratif. Bahasa figuratif secara umum mencakup semua bentuk gaya bahasa yang berbeda atau tidak biasa secara semantis atau gramatikal, misalnya melibatkan pola bunyi dan struktur kalimat maupun pengiasan makna (Wales, 2011, h. 161). Dengan demikian, bahasa figuratif mengacu pada: (1) majas yang melibatkan deviasi makna (trope), seperti metafora (pembandingan implisit antara suatu objek atau tenor dengan objek lain atau vehicle yang dipersepsikan sama); simile (pembandingan dua objek secara eksplisit menggunakan kata-kata seperti, bak, bagaikan, dan lain-lain); hiperbola (ungkapan yang melebih-lebihkan sesuatu); sinekdoki (pertautan sesuatu yang merupakan bagian dari sesuatu lainnya); metonimi (penggunaan 
suatu kata untuk mengungkapkan objek lainnya yang memiliki hubungan kedekatan, sebab akibat dan lain-lain); dan lain-lain serta (2) majas yang menciptakan pola struktur kalimat secara fonologis, morfologis dan sintaksis (scheme), seperti aliterasi (perulangan konsonan yang sama); paralelisme (kesejajaran fungsi gramatikal kata-kata); asonansi (perulangan vokal yang sama); dan bentuk repetisi lainnya.

Pemanfaatan bahasa figuratif menentukan bagaimana sebuah teks mengekspresikan makna secara berbeda (tidak klise) yang dalam stilistika dikenal dengan istilah de-familiarisasi. Konsep tersebut mengacu pada keyakinan bahwa ketika style sebuah teks sudah sering dijumpai, maka teks tersebut tidak menarik lagi karena tidak ada sesuatu yang baru atau segar di dalamnya (Norgaard dkk, 2010, h. 95). Untuk itu, diperlukan elemen yang tidak biasa dan lebih artistik sehingga audiens akan tertarik membacanya. Daya yang membuat audiens tertarik itu dikenal dengan konsep foregrounding atau penonjolan unsur style, baik berupa deviasi (penyimpangan norma linguistik secara gramatikal atau semantis seperti penggunaan makna kiasan, dan lainlain) serta repetisi (penyiasatan pola bunyi, struktur, diksi, seperti aliterasi dan paralelisme) yang menyimpang dari teknik berbahasa yang standar (Wales, 2011, h. 167).

\section{Metode}

Artikel ini menggunakan pendekatan kualitatif deskriptif karena berusaha mendeskripsikan suatu objek atau fenomena apa adanya (Sugiyono, 2010, h.59).Fenomena dimaksud bersifat kebahasaan dalam bentuk peribahasa yang populer di masyarakat Madura.

Karena jumlah peribahasa Madura banyak, maka sesuai dengan lingkup permasalahan, data artikel ini berupa peribahasa Madura yang memiliki relevansi dengan stereotip kekerasan pada suku Madura. Peribahasa-peribahasa tersebut diperoleh dari dua sumber tertulis, yaitu Kamus Madura-Indonesia Kontemporer karangan Muhri Mohtar (2010) dan buku berjudul Manusia Madura karangan Mien Ahmad Rifai (2007).

Berdasarkan jenis sumber data, metode pengumpulan data yang digunakan adalah documentary method dengan teknik simak. Menurut Merriam (2009, h.86), documentary method berupa pengumpulan data dari material tertulis maupun material lainnya yang relevan, seperti buku, catatan sipil, dokumen pribadi, dokumen visual dan budaya populer, serta artefak. Selanjutnya, menurut Kesuma (2007, h. 43), teknik simak merupakan cara pengumpulan data dengan kategorisasi bahan-bahan tertulis, baik dari sumber dokumen, buku, koran, majalah, dan lain-lain. Peribahasa yang ada di dalam dua sumber data di atas, dibaca, dicermati dan diseleksi berdasarkan maknanya yang relevan dengan tema stereotip kekerasan masyarakat Madura. Data yang sudah diperoleh kemudian diklasifikasikan berdasarkan tema makna dan dicatat ke dalam sebuah tabel.

Untuk menganalisis data, langkah pertama adalah mengidentifikasi jenis gaya bahasa figuratif yang dipakai beserta unsurnya. Langkah selanjutnya adalah mengidentifikasi aspek penonjolan atau foregrounding yang menjadi ciri stilistik dari setiap peribahasa dan mendeskripsikan makna yang dibangun oleh ciri-ciri tersebut. Setelah pendeskripsian makna dilakukan, kemudian dihubungkan dengan stereotip kekerasan pada etnis Madura. Pada tahap tersebut, dilakukan interpretasi tentang apakah pesan yang dibawa peribahasaperibahasa tersebut mendukung stereotip kekerasan pada etnis Madura.

\section{MAKNA PERIBAHASA MADURA DAN STEREOTIP KEKERASAN}

Berdasarkan analisis data yang dilakukan ditemukan bahwa dalam masyarakat Madura terdapat lima peribahasa yang berhubungan dengan stereotip kekerasan. Kelima peribahasa tersebut dipilih karena memiliki makna-makna yang merepresentasikan perspektif budaya Madura terhadap bentuk dan arti kekerasan itu sendiri. Jika diklasifikasikan, maka lima peribahasa tersebut mewakili tiga kategori makna yang menjelaskan tentang ihwal kekerasan, yaitu: (1) kekerasan fisik; (2) kekerasan dalam berpendirian; dan (3) nasihat tentang kekerasan. Dalam tabel 1, lima peribahasa Madura tersebut ditampilkan beserta makna leksikal masing-masing. 
Tabel 1. Peribahasa Madura dan makna leksikalnya

\begin{tabular}{|c|c|c|}
\hline No & $\begin{array}{l}\text { Kategori } \\
\text { Makna }\end{array}$ & $\begin{array}{c}\text { Peribahasa dan Makna } \\
\text { Leksikal }\end{array}$ \\
\hline 1. & Kekerasan fisik & $\begin{array}{l}\text { 1.Etembhang pote mata } \\
\text { ango'an pote tolang (Daripada } \\
\text { putih mata lebih baik putih } \\
\text { tulang) } \\
\text { 2. Lokana dhaghing bisa ejhai', } \\
\text { lokana ate tada' tambhana } \\
\text { kajhabhana ngero' dara } \\
\text { (Lukanya daging bisa dijahit, } \\
\text { lukanya hati tidak ada obatnya } \\
\text { kecuali minum darah) }\end{array}$ \\
\hline 2 & $\begin{array}{l}\text { Keras dalam } \\
\text { berpendirian }\end{array}$ & $\begin{array}{l}\text { 1. Kerras polana akerres } \\
\text { (Keras karena berkeris) } \\
\text { 2. Pakoh ngenneng ka kajuh } \\
\text { (Paku menancap di kayu) }\end{array}$ \\
\hline 3 & $\begin{array}{l}\text { Nasihat tentang } \\
\text { kekerasan }\end{array}$ & $\begin{array}{l}\text { Mara ola' samennet (Seperti } \\
\text { ulat bulu semenit) }\end{array}$ \\
\hline
\end{tabular}

Selanjutnya, setiap peribahasa akan dikaji dengan pendekatan stilistik melalui deskripsi unsur-unsur formalnya, seperti diksi, struktur kalimat dan lain-lain serta menjelaskan dampak fungsional unsur-unsur tersebut terhadap proses interpretasi makna peribahasa yang berkaitan dengan stereotip kekerasan etnis Madura.

\section{Kekerasan Fisik}

Peribahasa Madura yang sangat distereotipkan dengan kekerasan fisik etnis Madura adalah etembhang pote mata ango'an pote tolang. Secara konten, peribahasa ini dapat disamakan dengan peribahasa Melayu "Lebih baik mati berkalang tanah daripada hidup bercermin bangkai". Namun, peribahasa Melayu tersebut secara stilistik terdengar "apa adanya" karena kata-katanya tidak bersayap. Berbeda dengan versi Madura yang daya metaforisnya lebih menonjol karena maknanya tersembunyi di balik kata-kata pote mata dan pote tolang. Sehingga, dapat dikatakan bahwa dari aspek foregrounding, peribahasa ini jelas memiliki deviasi semantis karena makna yang dimaksud lebih bersifat intensional (konotatif) dan bukan aktual (denotatif). Ini yang membuatnya lebih defamiliar daripada peribahasa versi Melayu.

Secara konotatif, pote mata atau putih mata disini melambangkan rasa malu seseorang karena merasa harga dirinya telah direndahkan. Mengingat harga diri/martabat manusia sangat dijunjung oleh orang Madura, maka setiap bentuk pelanggaran terhadapnya merupakan sesuatu yang menimbulkan rasa malu (malo). Malu tersebut bisa diakibatkan oleh sebab-sebab tertentu, misalnya istrinya diselingkuhi atau urusan hutang piutang. Karena merasa sangat dipermalukan, orang Madura menjadi khawatir orang-orang di sekelilingnya akan mencemooh dirinya. Kondisi demikian digambarkan seperti bola mata yang tidak memiliki bagian berwarna hitam (pupil dan selaput pelangi). Pupil dan selaput pelangi secara anatomi adalah bagian mata yang menentukan kuantitas cahaya yang masuk ke bagian mata untuk diproses oleh lensa mata dan selanjutnya menuju saraf otak. Artinya, tanpa dua bagian tersebut, mata manusia tidak akan berfungsi dengan baik sebagai organ penglihatan. Maka, orang Madura menganalogikan bahwa putih mata adalah keadaan ketika manusia tidak sanggup melihat atau bertemu muka dengan siapapun karena harga dirinya sudah dilecehkan.

Bila pote mata lebih bersifat metaforis karena membandingkan rasa dipermalukan dengan putih mata, maka pote tolang atau putih tulang secara stilistik merupakan bentuk pemajasan metonimi. Terlihatnya warna tulang manusia dapat disebabkan karena adanya luka menganga yang merobek daging hingga terlihat bagian tulangnya. Luka demikian tentu disebabkan oleh pertarungan atau adu fisik yang dimungkinkan dapat menyebabkan pihak yang terlibat mengalami luka hingga kondisi yang ekstrem. Sehingga, "putih tulang" secara semantis memiliki hubungan sebab akibat dengan perkelahian sebagai referent. Dengan kata lain, frasa ini merepresentasikan pesan bahwa orang Madura tidak takut terluka apalagi mati karena berkelahi. Selama perkelahian itu dilakukan dengan jantan, hal itu lebih terhormat daripada dirinya kehilangan muka akibat menanggung malu (pote mata).

Selain deviasi sematis, ciri foregrounding atau penonjolan pada peribahasa ini ditandai juga dengan repetisi, yaitu berulangnya kata pote. Aspek perulangan kata ini juga menjadikan peribahasa ini menonjol dan tidak biasa (seperti halnya peribahasa Melayu di atas). Maka, penggunaan sarana deviasi dan repetisi membuat peribahasa ini memiliki efek estetis maksimal sehingga makna yang dikemukakan mendapat perhatian lebih. 
Peribahasa selanjutnya yang juga dapat memunculkan persepsi negatif tentang karakter keras etnis Madura adalah lokana dhaghing bisa ejhai', lokana ate tada' tambhana kajhabhana ngero' dara. Diksi dalam peribahasa ini memang terdengar dramatis dan hiperbolis sehingga berpotensi dianggap sebagai pembenaran terhadap stereotip bahwa orang Madura itu keras, beringas atau bahkan mungkin biadab. Secara stilistik, peribahasa ini merupakan sebuah metafora yang menjelaskan betapa sakit hati merupakan sesuatu yang serius bagi orang Madura hingga dideskripsikan bahwa tidak ada obatnya selain ngero' dara (minum darah) atau berkelahi hingga salah satu pihak yang bertikai mati.

Peribahasa ini mendayagunakan dua pemajasan sekaligus. Oleh karena itu, perlu dibagi menjadi dua klausa. Klausa pertama lokana dhaghing bisa ejhai' atau lukanya daging bisa dijahit merupakan kombinasi pemajasan sinekdoki dan metonimi karena kata daging merupakan bagian/representasi dari tubuh manusia sementara dijahit merupakan salah satu sarana atau cara mengobati luka pada tubuh manusia. Secara stilistik, klausa ini tidak mengandung pemindahan makna (transference of meaning) seperti halnya majas metafora. Makna yang dibawa tetap dapat dipahami tanpa membandingkan dengan entitas lain.

Di sisi lain, klausa berikutnya lokana ate tada' tambhana kajhabhana ngero' dara lebih bersifat metaforis karena aspek yang ditonjolkan (foregrounded) adalah deviasi semantis. Jelas disini terdapat penyimpangan makna denotatif. Walaupun salah satu elemennya dapat dikategorikan sebagai metafor usang (loka ate atau luka hati) seperti halnya kata sakit hati yang sudah lazim dalam bahasa sehari-hari, frasa ngero' dara disini merupakan metafora yang sangat kuat dan tidak dapat dimaknai secara literal bahwa obat sakit hati bagi orang Madura adalah dengan meminum darah. Tetapi, praktik minum darah adalah sarana (vehicle) yang mentransfer makna dari unsur tenor-nya, yaitu berkelahi atau pada derajat yang ekstrem hingga membunuh pihak yang telah merendahkan martabat diri seseorang. Bagi orang awam, tentu peribahasa ini dapat dimaknai bahwa orang Madura kejam dan biadab karena bila membunuh sampai meminum darah lawannya. Padahal, tidak demikian adanya. Frasa minum darah disini hanyalah sebuah ungkapan hiperbolis yang menggambarkan betapa perasaan orang Madura sangat sensitif sehingga bila sangat terusik dan tersakiti, apapun akan dilakukan oleh orang Madura untuk membalas dendam.

Di samping deviasi semantis akibat pemajasan, aspek foregrounding peribahasa ini juga repetisi kata lokana sebagai subjek pada awal kedua klausa. Sehingga, bentuk paralelisme peribahasa ini sangat menonjol. Apalagi, kata yang diulang adalah lokana atau lukanya. Dengan kata lain, peribahasa ini menitikberatkan pesan bahwa jangan mainmain dengan perasaan, apalagi sampai melukainya.

\section{Kekerasan dalam Berpendirian}

Peribahasa selanjutnya yang akan dibahas memiliki perbedaan perspektif dalam memandang kekerasan. Peribahasa kerras polana akerres bila dimaknai secara literal akan memberikan pembenaran tentang pembawaan orang Madura yang identik dengan senjata tajam. Padahal, makna intensionalnya adalah sifat keras/teguh bagi orang Madura diperlukan bila dia benar. Sebuah kebenaran harus dipertahankan dengan keberanian dan konsistensi. Seperti halnya peribahasa yang kental dengan figures of thought, peribahasa ini menonjolkan penyimpangan semantis karena pesannya tidak dapat dipahami berdasarkan makna denotatif. Pembawaan keras dalam peribahasa ini tidak semata-mata mengacu pada sifat kekerasan apalagi dengan menggunakan senjata tajam (keris). Keris disini harus dipahami sebagai representasi dari prinsip kebenaran. Keris yang secara fisik berupa besi berlekuk yang panjang dan lancip merupakan penggambaran sebuah kebenaran yang hakiki. Kebenaran yang mutlak dan tidak terbantahkan dicitrakan sekuat dan selancip keris. Artinya, keberanian orang Madura bukanlah keberanian yang membabi buta tetapi memiliki dasar atau "senjata" yang ampuh yaitu kebenaran. Keris berfungsi sebagai vehicle yang membawa pesan dari tenor (kebenaran). Kata keras juga tidak bermakna beringas tetapi sikap tegas dan konsisten. Maka, apapun yang dianggap benar, orang Madura akan kukuh dan teguh mempertahankannya. 
Secara struktur lahir, gaya aliterasi dan asonansi sangat kental dalam peribahasa ini karena terdapat perulangan bunyi konsonan kerras polana akerres dan vokal kerras polana akerres. Secara stilistik, penggunaan pola semacam itu sangat menonjolkan ketidaklaziman (de-familiarisasi) bahasa sehingga menciptakan efek puitis yang kuat dan pesannya menjadi mudah diingat.

Senada dengan kerras polana akerres, peribahasa pakoh ngenneng $\mathrm{ka}$ kajuh jelas mengandung deviasi semantis sebagai unsur foregrounding-nya karena tidak dapat dipahami maknanya secara harfiah. Peribahasa ini berpesan bahwa keteguhan orang Madura dalam memegang keyakinan dan pendirian harus kokoh seperti paku yang sudah tertancap pada kayu. Sekali tertancap, maka paku tersebut tidak akan goyah dan lepas. Begitu halnya dengan pendirian dan keteguhan sikap orang Madura. Dengan demikian, konsistensi ucapan dan perbuatan harus sekuat paku yang tertancap pada sebatang kayu.

Penggunaan pembanding (vehicle) dalam metafora peribahasa ini sebagai objek pembanding keteguhan sikap juga menunjukkan bagaimana preferensi orang Madura dalam menggunakan sarana kiasan. Secara fungsional, paku dan kayu merupakan alat pertukangan yang identik dengan pekerjaan kasar. Artinya, pemilihan dua objek tersebut sebagai pembanding secara tidak langsung bisa menggambarkan latar belakang orang Madura yang tidak asing dengan pekerjaan sesulit/sekasar apapun.

Selain aspek metaforis, aliterasi (perulangan konsonan) /h/ pada pakoh dan kajuh juga membuat peribahasa ini memiliki nilai estetis dan mudah diingat. Hasilnya, sebuah peribahasa bersajak yang bila dituturkan akan membuat makna yang dikemukakan mendapat perhatian lebih.

\section{Nasihat tentang Kekerasan}

Peribahasa kelima yang menjadi fokus kajian dalam artikel ini adalah mara ola' samennet. Karena adanya kata mara (seperti), peribahasa ini merupakan bentuk pemajasan simile yang efek foregrounding-nya adalah deviasi semantis dalam bentuk pembandingan dua hal secara eksplisit: ola' samennet atau ulat bulu semenit dengan orang yang memiliki sifat pemarah. Dibandingkan dengan peribahasa-peribahasa sebelumnya yang mengandung pemajasan metaforis, peribahasa ini lebih eksplisit. Untuk mengetahui bagaimana ciri seorang yang bertemperamen tinggi, tinggal membayangkan bagaimana seekor ulat bulu yang bila disentuh sedikit saja akan menggeliat-geliatkan tubuhnya. Dan bila manusia menyentuhnya, dalam waktu singkat (disini digambarkan dalam waktu semenit) kulit akan langsung terasa gatal. Demikian orang Madura mengibaratkan seseorang yang mudah marah atau mudah tersulut emosinya. Sedikit saja diusik, maka akan langsung bereaksi seperti ulat bulu. Bahkan, juga bisa melukai pihak yang dianggap mengusik atau membuatnya marah.

Tentu, secara kontekstual, umumnya peribahasa selalu berfungsi mengajarkan nilai kebijaksanaandan moral. Dalam hal ini, peribahasa mara ola' samennet berpesan agar jangan seperti ulat bulu. Jangan mau dibandingkan dengan seekor hewan kecil yang biasa menjadi hama tanaman. Penggunaan hewan seperti ulat sebagai vehicle juga memberikan efek asosiasi makna yang negatif yang tujuannya adalah sebagai kontrol sosial: kendalikan emosi kalau tidak ingin disamakan dengan ulat bulu. Dengan demikian, secara stilistik, peribahasa ini menggunakan deviasi makna sebagai ciri foregrounding-nya.

\section{HUBUNGAN PERIBAHASA MADURA DENGAN STEREOTIP KEKERASAN ETNIS MADURA}

Menurut Wardhaugh \& Fuller (2015, h. 418), stereotip merupakan generalisasi tentang sebuah kelompok masyarakat bahwa seluruh anggotanya memiliki karakteristik personal yang sama. Dengan kata lain, stereotip mencakup anggapan, penilaian atau pandangan eksternal terhadap suatu kelompok. Selama ini, stereotip yang disematkan pada suku Madura lebih banyak negatif sehingga menimbulkan kesalahpahaman di kalangan orang luar Madura. Stereotip suku Madura sudah terbentuk sejak zaman kolonialisme Belanda yang lebih ditujukan untuk mendukung kepentingan dominasi dan hegemoni penjajah. Dengan adanya stereotip tersebut, maka etnisetnis di Indonesia sulit bersatu. Namun, sayangnya sebagian stereotip tersebut masih ada yang bertahan hingga kini. 
Salah satu stereotip negatif yang masih diidentikkan dengan orang Madura adalah kekerasan terutama budaya menyelesaikan masalah dengan carok. Umumnya kekerasan dalam bentuk carok dilakukan oleh orang Madura karena mereka sangat menjunjung tinggi martabat/harga diri dan nama baik. Ketika martabat mereka direndahkan atau dilecehkan orang lain, maka dalam tingkat tertentu orang Madura akan merasa dipermalukan dan terhina yang secara kultur dikenal dengan konsep malo atau malu. Akibatnya, bagi orang Madura yang konservatif, tidak ada cara yang paling adil selain beradu carok. Sejalan dengan konsep folklor, menurut Rifai (2007, h. 204), salah satu tabiat mencolok orang Madura bagi orang luar adalah sikap dan tindak tanduknya yang terkesan gherra atau kaku dan kasar yang dipercaya salah satu penyebabnya karena pengaruh kondisi alam Pulau Madura yang gersang dan tandus. Karakter itu berpotensi bertahan terutama pada lapisan masyarakat pedesaan yang masih konservatif dan tingkat pendidikannya tidak memadai. Karena pembawaan orang Madura yang gherra (kaku dan kasar) serta bangalan (pemberani), jika tidak dikendalikan dengan baik akan muncul sifat dan perilaku negatif orang Madura seperti mudah tersinggung, naik darah dan suka berkelahi (Rifai, 2007, h. 280).

Padahal, bagi orang luar Madura yang pernah berinteraksi dan tinggal bersama masyarakat Madura, kendati mereka mengakui bahwa pada dasarnya orang Madura memang "keras", orang Madura juga bisa berperangai dan berperilaku sopan, santun, menghargai orang dan menjunjung persaudaraan (Wiyata, 2012). Walaupun praktik kekerasan di Madura perlu dipandang secara objektif dan tidak digeneralisasi, terjadinya kasus kekerasan dan pembunuhan melibatkan etnis Madura seperti konflik etnis di Kalimantan hingga kasus skala kecil yang akhir-akhir ini terjadi seolah menjustifikasi persepsi tentang orang Madura yang mudah emosional, beringas dan kejam.

Benarkah orang Madura itu keras? Jika merujuk pada analisis lima peribahasa di atas, tidak serta merta dapat dijawab secara hitam putih. Pertama, tindakan kekerasan misalnya carok yang dilakukan oleh orang Madura bukanlah tanpa sebab. Pasti ada alasan yang sangat kuat sehingga membuat orang Madura menggunakan kekerasan untuk menyelesaikan masalah. Dan, alasan paling mendasar adalah harga diri sehingga berkaitan dengan konsep malo atau malu yang sangat diyakini oleh masyarakat Madura. Pelecehan terhadap harga diri sebagai manusia merupakan sesuatu yang serius bagi orang Madura karena itu menandakan dirinya sudah tidak dipandang sebagai seorang makhluk sosial.Ketika harga diri dicederai, misalnya istrinya direbut laki-laki lain, orang Madura merasa hal tersebut mencoreng martabatnya sebagai laki-laki. Dia akan merasa malo atau sakit hati hingga tidak sanggup bertemu muka dengan siapapun (pote mata) sebelum dia menunjukkan upaya pembelaan harga dirinya dan sikap kejantanan.

Seperti diuraikan dalam landasan teori, masyarakat suku Madura percaya bahwa harga diri atau nama baik adalah suatu hal yang harus dipertahankan dan terlihat dari sebuah ungkapan rakyat Madura "nyama se sae paneka kodu esare ghu-ongghu, kodu eparlowaghi panyareepon, lebbiyaghi parlo dari panyareepon kasoghiyan" yang artinya nama baik (harga diri) harus diupayakan dengan sungguh-sungguh, lebih daripada harta benda (Imron, 2012). Dengan demikian, konsep harga diri sudah terinternalisasi dalam pemikiran masyarakat Madura. Namun, reaksi terhadap pelecehan harga diri tentu tidak dapat digeneralisasi. Apalagi jika dikaitkan dengan pesan dari peribahasa mara ola' samennet. Bagi orang yang bertemperamen tinggi, reaksinya bisa saja berlebihan sampai melakukan pembunuhan. Terutama pada lapisan masyarakat pedesaan yang pandangan hidupnya masih kolot dan tingkat pendidikannya rendah, tidak ada cara paling adil untuk membela harga diri yang terlecehkan selain ngero' dara (berkelahi). Namun, tentu tidak semua orang Madura itu temperamental. Apalagi pada masyarakat perkotaan yang sudah bersentuhan dengan arus modernisasi gaya hidup dan pola pikir, mereka tentu akan memilih bereaksi berdasarkan aturan, misalnya melalui jalur hukum.

Dengan demikian, kekerasan yang terjadi dalam masyarakat Madura pasti didasari oleh sebab yang kuat, terutama karena pelecehan harga diri misalnya pencorengan nama baik karena 
perselingkuhan, fitnah secara verbal, perebutan harta, hutang piutang, dan lain-lain, yang sifatnya kasuistik dan tidak dapat dinilai bahwa budaya Madura melegitimasi tindakan kekerasan secara membabi buta.

Kedua, karakter keras dalam budaya Madura tidak selalu dapat diidentikkan sebagai kekerasan fisik apalagi carok. Perilaku keras yang mengacu pada sikap menghadapi segala sesuatu dengan penuh emosi dan mengabaikan akal budi dan etika tentu sangat bertentangan dengan pesan dari mara ola' samennet. Namun, yang lebih tepat adalah kekerasan dalam arti ketegasan dan konsistensi dalam pembelaan nilai kebenaran sebagaimana ditunjukkan oleh peribahasa kerras polana akerres dan pakoh ngenneng ka kajuh. Dua peribahasa tersebut menunjukkan betapa nilai-nilai kebenaran dan konsistensi sangat dijunjung tinggi dalam budaya Madura. Orang Madura akan teguh membela sesuatu yang diyakininya benar dan dalam tingkat tertentu apapun akan dilakukan untuk membelanya. Bila perlu, perilaku keras ditunjukkan tapi tentu harus berkeris (akerres), artinya harus punya alasan dan dasar yang jelas. Ketika seseorang tidak memiliki dasar logis yang melegitimasi perilaku kerasnya, maka tindakan tersebut patut disalahkan.Dan ketika keyakinan sudah dipilih, orang Madura akan kukuh memegangnya, sekukuh paku yang tertancap di sebatang kayu.

Dalam konteks lain, refleksi ketegasan Madura pun tercermin melalui pemilihan warna. Seperti umum dilihat, warna khas yang disukai dalam masyarakat Madura adalah warna yang bernuansa tegas seperti mera (merah), celleng (hitam), bhiru (hijau) atau koneng (kuning) sementara hampir tidak pernah orang Madura memilih warna-warna "lembut" atau kurang tegas yang kalaupun terpaksa, biasanya dipilih hanya sebagai aksesoris tambahan (Wiyata, 2012).

\section{KESIMPULAN}

Berdasarkan temuan dan pembahasan di atas, dapat diambil beberapa kesimpulan tentang makna peribahasa Madura dan hubungannya dengan stereotip kekerasan etnis Madura. Pertama, peribahasa-peribahasa Madura kental dengan unsur-unsur figuratif, baik yang bersifat deviasi makna seperti metafora, simile, metonimi, sinekdoki dan hiperbola maupun penyiasatan struktur seperti aliterasi dan paralelisme. Selain itu, dari lima peribahasa yang dianalisis, empat peribahasa pertama menggunakan sarana deviasi semantis dan paralelisme atau repetisi struktur untuk memunculkan aspek foregrounding sedangkan peribahasa kelima hanya menggunakan sarana deviasi semantis. Unsur bahasa figuratif peribahasa pertama dan kedua mengekspresikan makna tentang pentingnya menjaga harga diri yang bila sekali dilecehkan harus dibela sungguh-sungguh dan bila perlu dipertaruhkan dengan nyawa. Unsur bahasa figuratif peribahasa ketiga dan keempat menonjolkan makna bahwa kekerasan tidak harus selalu mengacu pada kekerasan fisik namun ketegasan dan konsistensi dalam memperjuangkan nilai kebenaran yang diyakini. Sementara unsur bahasa figuratif peribahasa kelima menonjolkan makna bahwa pembawaan temperamental atau emosional adalah sesuatu yang harus dihindari.

Kedua, stereotip keras yang dilekatkan pada etnis Madura tidak sepenuhnya tepat karena kekerasan yang terjadi pada masyakarat Madura selalu dilandasi oleh sebab dan alasan yang kuat, terutama karena membela harga diri atau martabat seseorang. Stereotip keras juga tidak dapat diartikan semata-mata kekerasan secara fisik atau perkelahian tetapi berupa bentuk ketegasan sikap dan konsistensi dalam mengambil pilihan serta membela dan memperjuangkan apa yang sudah diyakini sebagai kebenaran. Stereotip keras yang dialamatkan kepada suku Madura tidak dapat digeneralisasi terhadap seluruh anggota masyarakat Madura apalagi dilekatkan pada budaya Madura karena berdasarkan peribahasa kelima, sifat mudah emosional dan tersinggung dalam kultur Madura juga merupakan suatu sikap yang sepatutnya dihindari.

Sebagai penutup, dihimbau kepada khalayak luas agar lebih bijak dan proporsional dalam menilai suatu kelompok masyarakat. Jangan sampai, kelompok masyarakat tersebut dihakimi dengan stereotip yang belum tentu merepresentasikan keadaan kelompok tersebut secara tepat. Perilaku positif maupun negatif pasti selalu ada dalam setiap kelompok masyarakat apapun dan dimanapun. Karena keterbatasan ruang dan waktu, artikel ini 
menyarankan perlunya kajian lebih mendalam terhadap bahasa figuratif peribahasa Madura dengan menggunakan sampel peribahasa yang lebih banyak. Bisa juga mempertimbangkan bentuk-bentuk peribahasa Madura lainnya.
Selain itu, perlu juga diidentifikasi kaitannya dengan stereotip-stereotip etnis Madura lainnya, baik yang positif maupun negatif. Sehingga, akan diperoleh gambaran yang lebih utuh tentang nilai-nilai budaya Madura.

\section{DAFTAR PUSTAKA}

Crystal, David. (1987). The Cambridge Encyclopedia of the English Language. Cambridge: Cambridge University Press.

Efawati, Rifa. (2013). Figuratif dalam Bahasa Madura: Kajian Semantik (Tesis). Yogyakarta: Universitas Gadjah Mada

Grzybek, Peter. (2014). Semiotic and Semantic Aspects of the Proverb dalam Hrisztova-Gotthardt,

Hrisztalina \& Aleksa Varga, Melita (Ed.). Introduction to Paremiology: A Comprehensive Guide to Proverb Studies. Berlin: De Gruyter

Imron. D.Zawawi. (2012). Mengenal Pandangan Hidup Orang Madura. Diakses pada 28Desember 2016 dari www.lontarmadura.com/mengenal-pandangan-hidup-orangmadura/

Kesuma, Tri Mastoyo Jati. (2007). Pengantar (Metode) Penelitian Bahasa. Yogyakarta: Carasvatibooks

Merriam, Sharan B. (2009). Qualitative Research: a Guide to Design and Implementation.San Francisco: Jossey-Bass.

Mieder, Wolfgang. (2004). Proverbs: A Handbook. Westpot: Greenwood Press

Misnadin. (2012). Nilai-Nilai Luhur Budaya dalam Pepatah-Pepatah Madura dalam Jurnal Atavisme Vol. 15 No. 1 halaman 75-84.

Mohtar, Muhri. (2010). Kamus Madura Indonesia Kontemporer. Tidak diterbitkan

Norgaard, Nina, Montoro, Rocio, dan Busse, Beatrix. (2010). Key Terms inStylistics.London: Continuum

Rifai, Mien Ahmad. (2007). Manusia Madura: Pembawaan, Perilaku, Etos Kerja, Penampilan, dan Pandangan Hidupnya seperti Dicitrakan Peribahasanya. Yogyakarta: Pilar Media

Sugiyono. (2014). Memahami Penelitian Kualitatif. Bandung: CV. Alfabeta

Wales, Katie. (2011). A Dictionary of Stylistics: $3^{\text {rd }}$ Edition. New York: Routledge

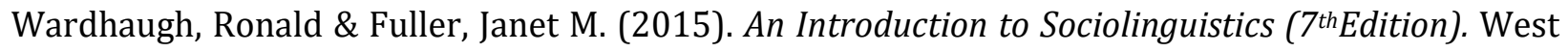
Sussex: Wiley Blackwell

Wiyata, A. Latief. (2012). Benarkah Orang Madura Keras? Diakses pada 28 Desember 2016 dari www.lontarmadura.com/benarkah-orang-madura-keras/\# 